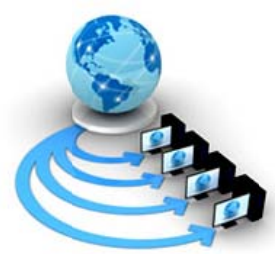

Volume 9, No. 1, January-February 2018

International Journal of Advanced Research in Computer Science

REVIEW ARTICLE

\author{
Available Online at www.ijarcs.info
}

\title{
A REVIEW: FUZZY LOGIC CONTROLLER (FLC) IN WIRELESS SENSOR NETWORKS (WSN)
}

\author{
Anju \\ M.Tech Student \\ Department of Electronics and Communication Engineering \\ RIEIT, Railmajra, India
}

\author{
Er. Manwinder Singh \\ Associate Professor \\ Department of Electronics and Communication Engineering \\ RIEIT, Railmajra, India
}

\begin{abstract}
The routing mechanisms are designed to inter-connect the nodes across the networks in dynamic domain. The wireless routing protocols must be empowered with dynamic memory management, which can be deployed with cooperative proactive routing or partial reactive routing mechanisms, which manages the different routing information on run-time memory. The multiple paths can also procured in routing table, which can be used to deploy the load balancing among the multiple paths selected using multipath reactive routing mechanism. In this paper, we have studied the various routing mechanism, which includes the multipath routing, personalized routing, inter-domain routing, joint traffic splitting, rate control mechanism and cognitive heterogeneous routing mechanisms. The comparative study of the latter models is performed, which are observed for their functional merits and demerits. The projected improvement has been observed in the form of segmental routing mechanism, which can handle the micro routes in the inter-domain routing mechanism for WSN.
\end{abstract}

Keywords- Sensor routing, IoT sensor, dynamic routing, intelligent routing.

\section{INTRODUCTION}

Introduction of Wireless mesh network: Wireless infrastructure is all about to ease of its core which is used to apply for a wide variety of network topologies for making it easily, quickly and cost-effectively. In case of of a mobile device, the wireless topology to the base station or access point builds the connection from point to multipoint structure as well as it uses the handoff between the cells. In general, from point-to-point wireless network, it uses the wire for interconnection among the cells. Instead of that, Those interrelations were implemented as a type of relay, which can easily redirect the traffic wirelessly from one cell to next, for making this configuration easier. So, that's the sphere of the wireless mesh. [1]

This wireless mesh network projects the configuration and may be expand for providing the dynamic and cost effective links over large geographic domain. On the other hand, an ad-hoc network provides the communication within the range of the every wireless device. [2] In the particular area, the routers may act as a cell and it will moved according to the definite demands. Often, the mesh router are not restricted as compared to another nodes in the terms of resources within the network. According to this way, the wireless interconnect network distinguish from an ad-hoc network, while all the resources are constrained by these nodes. [2-3]

Routing Introduction: A very simple way to explain the routing i.e. "learning how to get from here to there." (This is the model description of a route about the purpose by Shoch, which is tempered by such as realistic examination observation by Radia Perlman that routes the information from source node to destination node which is dependent; So that you have to know the starting point which isn't enough) [3] In a few cases, Routing is the process which is used for obtaining and distributing the information in very firm intelligence ("learning"), but the information we get from initial to final is not worth it (for which a dissimilar expression, forwarding, is reserved). As, this details are not useful but it is hard to grab the usefulness of this information. In general, Routing is the technique which refers to the things i.e. used to find out and publicize the way from here to there as well as shifts the packets from initial to final stage when needed. The peculiarity between routing and forwarding is conserved in the formal argument of the functions performed by Oss end systems and dissimilarity is consequential at the intermediate systems. [4]

\subsection{Categories of Routing Protocols}

1.1.1 Proactive Protocols: In Proactive or Table-Driven Routing Protocols, the network is continuously preserving the latest routes of each node to every another node. To maintain the reliability of routing table, the information is randomly transferring throughout the system. Hence, if a route has previously existed prior to traffic comes, then the transmission of the network can easily occurs without including any delay. [5] Otherwise, if the routes doesn't receive packets at the destination then it should wait in a queue. However, for exceedingly dynamic arrangement topology, the Proactive schemes involves a major amount of resources for keeping the routing information up-to-date as well as trustworthy. There are some Proactive Routing Protocols for instance DSDV, Wireless Routing Protocol (WRP), Global State Routing (GSR) and Cluster-head Gateway Switch Routing (CGSR). [5-6]

1.1.2 Reactive Protocols : In Reactive Protocols, Route discovers a node in the network only when we need to deliver the packets to its destination. For this reason, a node sets to a route discovery method in the course of the 
network. [6] When all the probably permutations and route have been examined then this course is concluded. Once a route is established, the route maintenance procedure is maintained until either the objective becomes difficult to get every path from the source or awaiting this process is no longer preferred. In Reactive proposal, nodes are maintained by the routes for active the destinations. For every unfamiliar destination the route explore is necessary. [7] As a result, theoretically the statement overhead is went down at outflow of delay because of route study. There are some Reactive Protocols such as Cluster Based Routing Protocol (CBRP), AODV, DSR, TORA, Signal Stability Routing (SSR) and Location Aided Routing (LAR).

\section{LITERATRE REVIEW}

Al-Saadi, Ahmed et. al. [8] worked towards the development of routing among the heterogeneous wireless networks. In this paper, the author has discussed the situation of Metropolitian networks, and works on the wireless standard IEEE 802.11. The WSN and 4G/LTE networks are the large scale wireless networks, and required to be handled efficiently over the issue of connectivity. Zhou Anfu et. al. [9] worked to develop a solution for the segregation of the network traffic in aggregated manner, scheduling of the wireless data connections and network rate control mechanism for the wireless networks. The authors are proposing the multiple gateway system to handle the higher amount of data for the optimal environments. Murugeswari, R. [10] has worked on the multi-objective evolutionary algorithm based QoS routing in Wireless Sensor Networks. This paper proposes a new model for routing in WSN by using Modified Non-dominated Sorting Genetic Algorithm-II (MNSGA-II). Sakamoto, Shinji et. al. [11] has worked on the implementation of a New Replacement Method for WSNs. Ghadimi, Euhanna et. al. [2] have proposed Opportunistic Routing in Low DutyCycled Wireless Sensor Networks. 2014 Sahin, Dilan et. al. [3] has worked upon QoS differentiation in single-path and multi-path routing for wireless sensor network-based smart grid applications. Wireless sensor network (WSN) concept places an important role in this modernization process of the power grid with its efficient and low-cost deployment characteristics. 2014 Singh, Dharmendra [4] et. al. has developed an energy efficient source based tree routing with time stamp in WSN. Wireless sensor network most recently used technology. Different routing protocols and topologies are used to transmit data from source to sink. 2012 Kwon, Kiwoong et. al. [5] has worked upon the stateless point to point routing protocol based on shortcut tree routing algorithm for IP-WSN. To address the routing challenges, the authors have proposed the Stateless P2P Routing protocol (SPR) based on shortcut tree routing algorithm which is our previous study. 2014 Tunca, Can, Sinan Isik, M. Donmez, and Cem Ersoy [6] have proposed a survey upon distributed mobile sink routing method for WSN. In this paper, the authors have presented a survey of the existing distributed mobile sink routing protocols. 2012 Bechkit, Walid et. al. [7] has worked on a new weighted shortest path tree for converge cast traffic routing in WSN. The authors have proposed in this paper a new weighted path cost function, and we show that the cost function is more suitable for WSN.
Table 2.1: Comparative Analysis of Various Routing Models

\begin{tabular}{|c|c|c|c|c|}
\hline Author & Title & $\begin{array}{l}\text { Technol } \\
\text { ogies } \\
\text { Used }\end{array}$ & Merits & $\begin{array}{l}\text { Demeri } \\
\text { ts }\end{array}$ \\
\hline $\begin{array}{l}\text { Ahmed Al- } \\
\text { Saadi, } \\
\text { Rossitza } \\
\text { Setchi, } \\
\text { Yulia } \\
\text { Hicks, } \\
\text { Stuart M. } \\
\text { Allen, } \\
\text { IEEE } \\
\text { TRANSAC } \\
\text { TIONS ON } \\
\text { VEHICUL } \\
\text { AR } \\
\text { TECHNOL } \\
\text { OGY, } \\
\text { VOL. 65, } \\
\text { NO. 12, } \\
\text { DECEMB } \\
\text { ER 2016 }\end{array}$ & $\begin{array}{l}\text { Routing } \\
\text { Protocol } \\
\text { for } \\
\text { Heterog } \\
\text { eneous } \\
\text { Wireles } \\
\text { s Sensor } \\
\text { Networ } \\
\text { ks }\end{array}$ & $\begin{array}{l}\text { Cognitiv } \\
\text { e } \\
\text { Heteroge } \\
\text { neous } \\
\text { routing } \\
\text { with } \\
\text { WiFi } \\
\text { integratio } \\
\text { n over } \\
\text { LTE } \\
\text { networks }\end{array}$ & $\begin{array}{l}\text { Efficient to } \\
\text { handle the } \\
\text { heavy } \\
\text { traffic. } \\
\text { Robust to } \\
\text { handle the } \\
\text { directional } \\
\text { routes for } \\
\text { moving } \\
\text { nodes. }\end{array}$ & $\begin{array}{l}\text { Updates } \\
\text { the } \\
\text { complet } \\
\text { e path, } \\
\text { whenev } \\
\text { er } \\
\text { required } \\
\text { - } \\
\text { Does } \\
\text { not } \\
\text { incorpor } \\
\text { ate the } \\
\text { segment } \\
\text { al or } \\
\text { phase } \\
\text { routing. }\end{array}$ \\
\hline $\begin{array}{l}\text { Manlio De } \\
\text { Domenico, } \\
\text { Antonio } \\
\text { Lima, } \\
\text { Marta } \\
\text { C González } \\
\text { and Alex } \\
\text { Arenas, } \\
\text { EPJ Data } \\
\text { Science } \\
\text { (2015) }\end{array}$ & $\begin{array}{l}\text { Persona } \\
\text { lized } \\
\text { routing } \\
\text { for } \\
\text { multitud } \\
\text { es in } \\
\text { smart } \\
\text { cities }\end{array}$ & $\begin{array}{l}\text { Distribut } \\
\text { ed } \\
\text { routing } \\
\text { with } \\
\text { personali } \\
\text { zed maps } \\
\text { establish } \\
\text { es the } \\
\text { vigorous } \\
\text { routing } \\
\text { mechanis } \\
\text { m. }\end{array}$ & $\begin{array}{l}\text { Adaptable } \\
\text { to Big Data } \\
\text { situation } \\
\text { (heavier } \\
\text { data loads) } \\
\text { Handles the } \\
\text { individual } \\
\text { or group } \\
\text { paths } \\
\text { towards the } \\
\text { similar } \\
\text { source, }\end{array}$ & $\begin{array}{l}\text { Does } \\
\text { not } \\
\text { account } \\
\text { the path } \\
\text { manipul } \\
\text { ation. } \\
\text { Conver } \\
\text { ge the } \\
\text { complet } \\
\text { e path } \\
\text { in the } \\
\text { path } \\
\text { failure } \\
\text { situatio } \\
\text { n. }\end{array}$ \\
\hline $\begin{array}{l}\text { Murugeswa } \\
\text { ri, R. } \\
\text { Elsevier, } \\
\text { December } \\
2015\end{array}$ & $\begin{array}{l}\text { A multi- } \\
\text { objectiv } \\
\text { e } \\
\text { evolutio } \\
\text { nary } \\
\text { algorith } \\
\text { m based } \\
\text { QoS } \\
\text { routing } \\
\text { in } \\
\text { Wireles } \\
\text { s Sensor } \\
\text { Networ } \\
\text { ks }\end{array}$ & $\begin{array}{l}\text { Dynamic } \\
\text { crowding } \\
\text { distance } \\
\text { with } \\
\text { quality of } \\
\text { service }\end{array}$ & $\begin{array}{l}\text { Utilizes the } \\
\text { Patero } \\
\text { graph to } \\
\text { compute } \\
\text { best } \\
\text { solution. } \\
\text { Establishes } \\
\text { the low } \\
\text { delay } \\
\text { situations. }\end{array}$ & $\begin{array}{l}\text { Does } \\
\text { not } \\
\text { work } \\
\text { towards } \\
\text { path } \\
\text { repairin } \\
\text { g. } \\
\text { Uses } \\
\text { comple } \\
\text { x } \\
\text { solution } \\
\text { to } \\
\text { update } \\
\text { the } \\
\text { path. }\end{array}$ \\
\hline $\begin{array}{l}\text { Anfu Zhou, } \\
\text { Min Liu, } \\
\text { Zhongchen } \\
\text { g Li, Eryk }\end{array}$ & $\begin{array}{l}\text { Joint } \\
\text { Traffic } \\
\text { Splittin } \\
\text { g, Rate }\end{array}$ & $\begin{array}{l}\text { Traffic } \\
\text { shaping } \\
\text { with } \\
\text { dynamic }\end{array}$ & $\begin{array}{l}\text { Adapt to } \\
\text { different } \\
\text { situations } \\
\text { with } \\
\end{array}$ & $\begin{array}{l}\text { No } \\
\text { dynami } \\
\text { c hop- } \\
\text { to-hop }\end{array}$ \\
\hline
\end{tabular}




\begin{tabular}{|c|c|c|c|c|}
\hline $\begin{array}{l}\text { Dutkiewicz } \\
\text {, IEEE } \\
\text { Transaction } \\
\mathrm{s} \text { on } \\
\text { Vehicular } \\
\text { Technolog } \\
\mathrm{y}, 2015\end{array}$ & $\begin{array}{l}\text { Control, } \\
\text { Routing } \\
\text { and } \\
\text { Schedul } \\
\text { ing } \\
\text { Algorith } \\
\text { m for } \\
\text { Maximi } \\
\text { zing } \\
\text { Networ } \\
\text { k } \\
\text { Utility } \\
\text { in } \\
\text { Wireles } \\
\text { s Sensor } \\
\text { Networ } \\
\text { ks }\end{array}$ & $\begin{array}{l}\text { traffic } \\
\text { rate } \\
\text { control } \\
\text { mechanis } \\
\text { m. }\end{array}$ & $\begin{array}{l}\text { dynamic } \\
\text { properties. } \\
\text { Scheduling } \\
\text { model } \\
\text { enables the } \\
\text { time slots } \\
\text { for the } \\
\text { users to } \\
\text { receive and } \\
\text { transmit } \\
\text { data. }\end{array}$ & $\begin{array}{l}\text { path } \\
\text { manipul } \\
\text { ation } \\
\text { program } \\
\text {. }\end{array}$ \\
\hline $\begin{array}{l}\text { Igor } \\
\text { Ganichev, } \\
\text { Bin Dai, P. } \\
\text { Brighten } \\
\text { Godfrey, } \\
\text { Scott } \\
\text { Shenker, } \\
\text { ACM } \\
\text { SIGCOM } \\
\text { M } \\
\text { Computer } \\
\text { Communic } \\
\text { ation } \\
\text { Review, } \\
\text { October } \\
\text { 2010 }\end{array}$ & $\begin{array}{l}\text { YAMR: } \\
\text { Yet } \\
\text { Another } \\
\text { Multipa } \\
\text { th } \\
\text { Routing } \\
\text { Protocol }\end{array}$ & $\begin{array}{l}\text { External } \\
\text { Routing } \\
\text { protocol } \\
\text { with } \\
\text { inter- } \\
\text { autonom } \\
\text { ous } \\
\text { system } \\
\text { routing } \\
\text { capabilit } \\
\text { y. }\end{array}$ & $\begin{array}{l}\text { Works on } \\
\text { multiple } \\
\text { paths } \\
\text { simultaneo } \\
\text { usly. } \\
\text { Creates the } \\
\text { dynamic } \\
\text { inter- } \\
\text { domain } \\
\text { links. }\end{array}$ & $\begin{array}{l}\text { Distanc } \\
\text { e vector } \\
\text { non- } \\
\text { segment } \\
\text { al route } \\
\text { update. } \\
\text { Path } \\
\text { quality } \\
\text { is not } \\
\text { consider } \\
\text { ed } \\
\text { properly } \\
\text {. }\end{array}$ \\
\hline $\begin{array}{l}\text { Wen Xu } \\
\text { and } \\
\text { Jennifer } \\
\text { Rexford, } \\
\text { SIGCOM } \\
\text { M, } \\
\text { September } \\
\text { 2006 }\end{array}$ & $\begin{array}{l}\text { MIRO: } \\
\text { Multi- } \\
\text { path } \\
\text { Interdo } \\
\text { main } \\
\text { ROutin } \\
\text { g }\end{array}$ & $\begin{array}{l}\text { Inter- } \\
\text { domain } \\
\& \quad \text { inter } \\
\text { autonom } \\
\text { ous } \\
\text { system } \\
\text { routing } \\
\text { with } \\
\text { dynamic } \\
\text { multipath } \\
\text { capabilit } \\
\text { y. }\end{array}$ & $\begin{array}{l}\text { Choose } \\
\text { dynamic } \\
\text { and best } \\
\text { performing } \\
\text { paths. } \\
\text { Implements } \\
\text { scalable } \\
\text { autonomou } \\
\text { s system } \\
\text { routing. }\end{array}$ & $\begin{array}{l}\text { Recogni } \\
\text { ze the } \\
\text { whole } \\
\text { path } \\
\text { from } \\
\text { source } \\
\text { to } \\
\text { destinati } \\
\text { on. } \\
\text { Doesn't } \\
\text { recogni } \\
\text { ze local } \\
\text { paths } \\
\text { under } \\
\text { the } \\
\text { autono } \\
\text { mous } \\
\text { systems }\end{array}$ \\
\hline
\end{tabular}

\section{PROPOSED WORK}

\subsection{Workflow Analysis of Existing Models}

Cognitive heterogeneous routing: The cognitive heterogeneous routing is the mechanism is specifically designed to transmit the data across the longer paths by using the multiple network parameters. This scheme has been developed with island nodes and interference awareness, which are the primary factors used to determine the path between the source and the destination.

Personalized routing mechanism: The synergetic routing scheme has been proposed in this model, where the route for each of the user is maintained and updated individually in order to reduce the overall load on the network as well as to ensure the best network availability to all users. The personalized paths are accounted with higher order of mandate in order to establish the higher level of flexibility and maintenance.

Multi-objective routing: This algorithm denies the use of dominated nodes, and provokes the routing mechanisms equipped with non-dominating set. The dynamically sorted genetic algorithm has been incorporated in this model to achieve the mechanism of dynamic crowding distance (CDC).

Joint traffic splitting and control routing: This scheme is the ensemble routing mechanism with high ability to handle the traffic segmentation, data flow control mechanism along with routing and scheduling to establish the robust network. This scheme has been derived to maximize the network resource utilization in order to create a balanced network across the WSNs.

YAMR: This model is designed to incorporate the multipath routing across the autonomous domains with increased ability to control the network services. The YAMR model has been designed with ability to manage multiple parallel paths than the BGP algorithm to handle the higher volumes of inter-domain data routing.

MIRO: This scheme is utilized to increase the data processing capability of each of the autonomous domain and eventually increase the capacity to handle the higher amounts of data with higher efficiency. This scheme enables the transit domains to take control over the flow of the traffic among various network segments within the domain.

The cognitive heterogeneous routing (Ahmed Al-Saadi, 2016), personalized routing mechanism (Manlio De Domenico, 2015) and multi-objective routing (Murugeswari, R., 2016) schemes describes the dynamic capability of the features, which includes the quality of service (QoS), heterogeneity and personalization of the routes in the smart cities has been discussed in these models. The joint traffic splitting and control routing (Anfu Zhou, 2015) model has been designed for the traffic shaping and data generation rate control mechanism to control the transmission rate of the egress traffic from the target nodes in the given wireless network. YAMR (Igor Ganichev, 2010) is the inter-domain routing with the capability of multiple paths selection, which adaptively works with the dynamic inter-domain handling. MIRO (Wen Xu, 2006) has been designed to enable the multiple path routing across the wireless networks in the inter-domain networking paradigm. MIRO has been designed as the dynamic and scalable routing protocol. The common problem of all of the studied routing protocols lies in their incapability to handle the segmented or micro path routing, which must be capable of dividing and dynamically managing the route in the smaller segments. Also, the pro- 
active dynamic multipath routing for load balancing can be efficiently deployed over the segmental routing.

\section{FINDINGS OF LITERATURE REVIEW}

The existing model is not capable of handling the dynamic routing for the mobile nodes in the given heterogeneous wireless mesh network. The handling of the dynamic routes for the mobile nodes in the case of wearable devices, healthcare tracking equipments, vehicular networks, etc becomes mandatory in the smart cities, and must be incorporated to make the wider adaptability of the target systems.

The existing model is also not capable of handling the dynamic internal routing table, which must be incorporated in order to handle the mobility of the nodes within the zone and out of the mesh network zone. The micro or segmental route updates as well as the complete route updates mechanism can be utilized dynamically to facilitate the high order mobility from zone to zone. The existing model is tested with maximum 30 nodes, which is not sufficient to handle the internet of things (IoT) clusters. The incorporation of this model in the case IoT requires many critical improving, which includes the handling of the different kinds of data, data stream interoperability and smart route selection mechanism to minimize the network load for the efficient routing among the IoT clusters.

\section{CONCLUSION}

The existing models are studied under the literature review section for this paper in order to critically analyze their functional design. This model focuses upon the different routing metric calculation methods for the wireless networks, which includes the distance methods such as hop count, bandwidth, reliability, etc. In this paper, the primary focus remains upon the selection of routes among the wireless networks in the presence of the connectivity holes such as black-hole, wormhole, etc. The fuzzy based routing has been proposed in the proposed model, which computes the routes on the basis of multiple parameters. These parameters include the network and security based parameters to compute the best and reliable route between random nodes A and B among the given network segment. The proposed model will be a preventive as well as detection mechanism. Hence, this mechanism would be developed as robust and balanced situation in the wireless networks. The new algorithm will be capable of computing and producing the best route among the nodes with highest reliability in order to prevent the connectivity hole nodes from the network routes.

\section{REFERENCES}

[1] Delaney, D., Russell Higgs, and G. O'Hare. "A stable routing framework for tree-based routing structures in wsns." (2014): 1-1.

[2] Ghadimi, Euhanna, Olaf Landsiedel, Pablo Soldati, Simon Duquennoy, and Mikael Johansson. "Opportunistic Routing in Low Duty-Cycled Wireless Sensor Networks." ACM Transactions on Sensor Networks 10, no. 4 (2014).

[3] Sahin, Dilan, Vehbi Cagri Gungor, Taskin Kocak, and Gurkan Tuna. "Quality-of-service differentiation in single-path and multi-path routing for wireless sensor network-based smart grid applications." Ad Hoc Networks (2014).

[4] Singh, Dharmendra, Shubhanjali Sharma, Vinesh Jain, and Jyoti Gajrani. "Energy efficient source based tree routing with time stamp in WSN." In Signal Propagation and Computer Technology (ICSPCT), 2014 International Conference on, pp. 120-124. IEEE, 2014.

[5] Kwon, Kiwoong, Minkeun Ha, Taehong Kim, Seong Hoon Kim, and Daeyoung Kim. "The stateless point to point routing protocol based on shortcut tree routing algorithm for IP-WSN." In Internet of Things (IOT), 2012 3rd International Conference on the, pp. 167-174. IEEE, 2012.

[6] Tunca, Can, Sinan Isik, M. Donmez, and Cem Ersoy. "Distributed Mobile Sink Routing for Wireless Sensor Networks: A Survey." (2014): 1-21.

[7] Bechkit, Walid, Mouloud Koudil, Yacine Challal, Abdelmadjid Bouabdallah, Brahim Souici, and Karima Benatchba. "A new weighted shortest path tree for convergecast traffic routing in WSN." In Computers and Communications (ISCC), 2012 IEEE Symposium on, pp. 000187-000192. IEEE, 2012.

Al-Saadi, Ahmed, Rossitza Setchi, Yulia Hicks, and Stuart M. Allen. "Routing Protocol for Heterogeneous Wireless Sensor Networks." IEEE Transactions on Vehicular Technology 65, no. 12 (2016): 9773-9786.

Zhou, Anfu, Min Liu, Zhongcheng Li, and Eryk Dutkiewicz. "Joint Traffic Splitting, Rate Control, Routing, and Scheduling Algorithm for Maximizing Network Utility in Wireless Sensor Networks." IEEE Transactions on Vehicular Technology 65, no. 4 (2016): 2688-2702.

[10] Murugeswari, R., S. Radhakrishnan, and D. Devaraj. "A multi-objective evolutionary algorithm based QoS routing in Wireless Sensor Networks." Applied Soft Computing 40 (2016): 517-525.

[11] Sakamoto, Shinji, Tetsuya Oda, Makoto Ikeda, Leonard Barolli, and Fatos Xhafa. "Implementation of a New Replacement Method in WSN-PSO Simulation System and Its Performance Evaluation." In Advanced Information Networking and Applications (AINA), 2016 IEEE 30th International Conference on, pp. 206-211. IEEE, 2016. 